\title{
Efek Variasi Penambahan Carbomer Terhadap Nilai pH, Viskositas dan Aktivitas Mikroba Pada Sediaan Hand Sanitizer
}

\author{
Melysa Putri ${ }^{1}$, Hafnimardiyanti ${ }^{1}$, Dian Savitri ${ }^{1}$

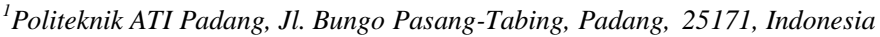

\section{ARTICLE INFORMATION}

Received: November 30, 2021

Revised: December 23, 2021

Available online: December 29, 2021

\section{KEYWORDS}

Carbomer, Hand Sanitizer, Microbial Activity $\mathrm{pH}$, Viscosity

\section{CORRESPONDENCE}

Name: Melysa Putri

E-mail: melysap27@gmail.com

\section{A B S T R A C T}

Hand sanitizer is an antiseptic in gel form. The gel texture in hand sanitizers is caused by the carbomer which acts as a gelling agent. Therefore, this research was done to observe the effect of carbomer on the value of $\mathrm{pH}$, viscosity, and microbial activity in hand sanitizers. As for testing $\mathrm{pH}$ using $\mathrm{pH}$ meters, testing viscosity was carried out using the viscometer method, while microbial activity was carried out using the Total Plate Number, Yeast Mold Number and microbial pathogen tests. Based on the data obtained, the carbomer greatly influences the increase in the viscosity of the hand sanitizer gel, the $\mathrm{pH}$ value was obtained at $6.0-7.06$, while in the microbial activity test none of the microbes grew in each medium. Therefore, it can be concluded that the hand sanitizer with code P3 is the best sample

\section{PENDAHULUAN}

Beragam mikroorganisme seperti jamur, bakteri, dan virus dapat melekat pada tangan manusia melalui sentuhan fisik. Salah satu cara untuk menghindari penyebaran dari mikroorganisme tersebut adalah membasuh tangan dengan sabun yang disertai dengan air yang mengalir. Membasuh tangan merupakan aktivitas sederhana yang bertujuan untuk menghilangkan kotoran dan mikroorganisme yang melekat di tangan dan telapak tangan. [1,2].

Membasuh tangan dengan sabun dan air mengalir terbukti dapat mencegah penyebaran dan pertumbuhan mikroorganisme hingga 90\%. Akan tetapi, mikroorganisme tersebut dapat kembali menyebar dalam 8 jam. Oleh karena itu, diperlukan solusi lain dalam menangani penyebaran infeksi mikroorganisme ini. Salah satu inovasi yang telah dikembangkan terhadap produk pembersih tangan adalah berupa produk pembersih tangan tanpa air, yang dikenal dengan hand sanitizer [3].

Hand sanitizer adalah bahan antiseptik berupa gel yang dapat mematikan kuman dalam waktu singkat. Hal ini dapat terjadi karena hand sanitizer mengandung senyawa golongan alkohol seperti etanol, propanol, isopropanol dengan konsentrasi $\pm 60-80 \%$. Selain itu, di dalam hand sanitizer juga terdapat senyawa fenol seperti klorheksidin dan triklosan. Senyawa yang terkandung dalam hand sanitizer ini akan mendenaturasi dan mengkoagulasi protein sel kuman sehingga ampuh dalam mematikan kuman [4].

Pada umumnya, hand sanitizer dibuat dalam bentuk gel yang lembut dan nyaman di kulit. Untuk membentuk tekstur gel diperlukan suatu gelling agent yang bertindak sebagai penyusun konsistensi sediaan gel. Salah satu gelling agent yang dapat digunakan adalah carbomer. Carbomer yang ditambahkan dengan suatu elektrolit dan diatur $\mathrm{pH}$ nya akan membentuk suatu polimer dengan viskositas tertentu [5].

Carbomer bertindak sebagai gelling agent yang biasanya digunakan dalam basis gel yang setiap struktur senyawa kimianya memiliki gugus karboksilat yang bersifat asam ketika kontak dengan air. Oleh karena itu, diperlukan suatu basa sebagai penetral seperti trietanolamin yang akan menyebabkan terjadinya ionisasi dan obat yang 
terlarut dalam air dapat masuk dan terperangkap dalam struktur tetapi dapat keluar kembali [6].

Berdasarkan penjabaran tersebut, pada penelitian ini peneliti bermaksud untuk mempelajari pengaruh penambahan carbomer yang berbeda terhadap nilai $\mathrm{pH}$, viskositas, dan aktivitas mikroba pada hand sanitizer yang dihasilkan.

\section{METODOLOGI}

Pembuatan handsanitizer ini dilakukan di Politeknik ATI Padang. Adapun peralatan yang dgunakan adalah neraca analitik, gelas piala $500 \mathrm{~mL}$, gelas piala $250 \mathrm{~mL}$, kaca arloji, spatula, hot plate, homomixer, cawan petri, jarum ose, pipet takar $10 \mathrm{~mL}$, bunsen, tabung reaksi, rak tabung reaksi, Laminar Air Flow (LAF), viskometer Brookfield, $\mathrm{pH}$ meter, dan spindle. Adapun bahan-bahan yang digunakan pada penelitian ini adalah carbomer, TEA (Triethanolamine), metil paraben, gliserin, triklosan, alkohol 70\%, aquadest, TSA (Trypticase Soya Agar), SDA (Sabouraud Dextrose Agar), MSA (Manitol Salt Agar), CA (Cetrimide Agar), TSB (Tryptic Soy Broth), SDB (Sabouraud Dextrose Broth).

\section{Pembuatan Hand Sanitizer}

Hand sanitizer dibuat dalam beberapa variasi formula seperti yang terlihat pada tabel 1 .

Tabel 1. Fromulasi Hand sanitizer

\begin{tabular}{lccccc}
\hline & $\mathrm{P}_{1}$ & $\mathrm{P}_{2}$ & $\mathrm{P}_{3}$ & $\mathrm{P}_{4}$ & $\mathrm{P}_{5}$ \\
\hline Carbomer $(\mathrm{g})$ & 0,2 & 0,5 & 1,0 & 1,5 & 2,0 \\
TEA $(\mathrm{g})$ & 0,1 & 0,2 & 0,3 & 0,5 & 0,6 \\
Triklosan $(\mathrm{g})$ & 4 & 4 & 4 & 4 & 4 \\
Gliserin $(\mathrm{g})$ & 2 & 2 & 2 & 2 & 2 \\
Alkohol 70\% (g) & 120 & 120 & 120 & 120 & 120 \\
Metil Paraben (g) & 0,2 & 0,2 & 0,2 & 0,2 & 0,2 \\
Aquadest $(\mathrm{g})$ & 73,3 & 72,9 & 72,3 & 71,6 & 71 \\
\hline
\end{tabular}

Masing-masing aquadest ditimbang dan dimasukkan ke dalam masing-masing gelas piala. Carbomer dan trietanolamin ditambahkan ke dalam masing-masing gelas piala sesuai dengan tabel 1 . Kemudian, campuran dipanaskan hingga suhu $70^{\circ} \mathrm{C}$ dan selanjutnya dihomogenkan menggunakan homomixer selama 1 menit. Setelah homogen, campuran tersebut ditambahkan gliserin, alkohol 70\%, dan metil paraben. Metil paraben yang ditambahkan ke dalam campuran tersebut, sebelumnya harus dilarutkan terlebih dahulu dalam $2 \mathrm{~g}$ aquadest. Terakhir, trietanolamin dimasukkan ke dalam masing-masing campuran sesuai dengan tabel 1.

Selanjutnya campuran dihomogenkan menggunakan homomixer $[7,8,9]$.

\section{Uji Viskositas Hand Sanitizer}

Masing-masing produk hand sanitizer dimasukkan ke dalam gelas piala. Spindel yang akan digunakan, dipasang pada tempat spindel dan diputar hingga pas. Kemudian, alat viskometer Brookfield dijalankan dan skala yang ditunjukkan oleh jarum viskometer tersebut dicatat. Pengujian dilakukan sebanyak tiga kali. Nilai viskositas zat ditentukan dengan cara melihat tabel skala, lalu hasil viskositas sediaan dicatat [10].

\section{Uji pH Hand Sanitizer}

$\mathrm{pH}$ Hand sanitizer diukur dengan menggunakan alat $\mathrm{pH}$ meter [11].

\section{Angka Lempeng Total dan Angka Kapang Khamir}

Sebelum melakukan pekerjaan, seluruh area kerja harus disterilisasi terlebih dahulu dengan menggunakan alkohol 70\%. Semua medium yang digunakan juga disterilkan terlebih dahulu dengan menggunakan autoklaf pada suhu $121^{\circ} \mathrm{C}$ selama 15 menit. Sampel yang akan diuji ditimbang sebanyak $1 \mathrm{~g}$ dan dimasukkan ke dalam medium TSB steril (pengenceran 10 $0^{-1}$ ) dan medium SDB steril (pengenceran $10^{-1}$ ). Inokulum yang berasal dari medium TSB dipipet sebanyak $4 \mathrm{~mL}$ dan ditebar ke dalam cawan petri steril. Sedangkan inokulum yang diencerkan dalam medium SDB dipipet $1 \mathrm{~mL}$ dan ditebar ke dalam cawan petri steril. Kemudian, setiap cawan petri diisi dengan $20 \mathrm{~mL}$ medium TSA dan SDA, dihomogenkan. Inokulum yang ditumbuhkan dalam medium TSA diinkubasi pada suhu $37^{\circ} \mathrm{C}$ selama 48 jam, sedangkan inokulum yang ditumbuhkan dalam medium SDA diinkubasi selama 2-5 hari pada suhu $25^{\circ} \mathrm{C}$. Pengujian dilakukan secara duplo.

\section{Uji Mikroba Patogen}

Media MSA dan NA steril dituangkan ke dalam cawan petri, lalu ditunggu sampai media memadat. Kemudian setiap sampel ditimbang sebanyak \pm 1 g. Lalu sampel digoreskan pada media padat MSA untuk menguji bakteri Staphylococcus aureus dan NA untuk menguji bakteri Pseudomonas aeruginosa. Kemudian cawan petri yang berisi MSA dan NA dimasukkan ke dalam inkubator dengan suhu $37^{\circ} \mathrm{C}$ selama 24 jam (1 hari). Setelah masa inkubasi selesai, dihitung mikroba yang tumbuh pada cawan petri [12].

Rumus penentuan uji mikroba patogen dapat dilihat pada rumus (1) :

$$
C F U=\frac{\text { Jumlah koloni bakteri }}{\text { Faktor pengenceran } \times \text { Sampel yang dituang }}
$$




\section{HASIL DAN PEMBAHASAN}

Produk hand sanitizer yang telah dibuat peneliti dengan beberapa variasi jumlah penambahan carbomer diuji stabilitasnya terhadap $\mathrm{pH}$ dan viskositasnya. Pada gambar 1 terlihat bahwa adanya pengaruh variasi penambahan carbomer terhadap $\mathrm{pH}$ dari produk hand sanitizer.

\section{Pengaruh Variasi Penambahan Carbomer} Terhadap pH Hand Sanitizer

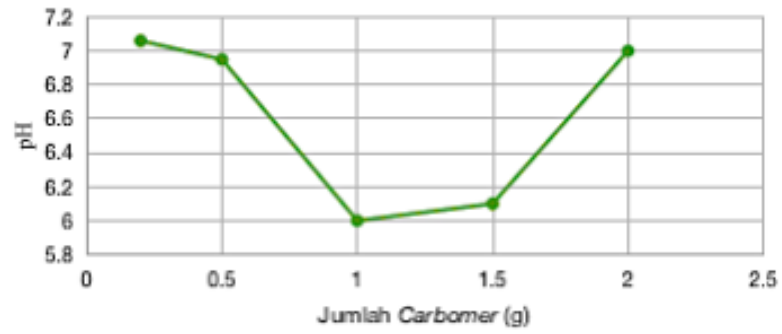

Gambar 1. Grafik Pengaruh Variasi Penambahan Carbomer Terhadap pH Hand sanitizer

Pengujian $\mathrm{pH}$ pada produk hand sanitizer ini bermaksud untuk menyesuaikan $\mathrm{pH}$ produk dengan $\mathrm{pH}$ kulit manusia. Berdasarkan Standar Nasional Indonesia (SNI) No. 06-2588-1992, $\mathrm{pH}$ hand sanitizer harus berkisar antara 4,5 - 6,5, karena pada kisaran $\mathrm{pH}$ ini mendekati $\mathrm{pH}$ fisiologis kulit manusia. Berdasarkan gambar 1 dapat dilihat bahwa $\mathrm{pH} \mathrm{P}_{3}$ dan $\mathrm{P}_{4}$ dengan penambahan carbomer sebanyak $0,5 \mathrm{~g}$ dan $1 \mathrm{~g}$ yang paling sesuai dengan SNI [13].

Sedangkan untuk pengujian viskositas hand sanitizer ini dapat dilihat pada gambar 2. Viskositas memperlihatkan derajat kekentalan dari sediaan gel. Standar viskositas pada hand sanitizer menurut Standar Nasional Indonesia (SNI) No. 06-2588-1992 adalah 5000 - 8000 cps. Berdasarkan gambar 2, dapat dilihat bahwa hand sanitizer yang memenuhi Standar Nasional Indonesia adalah hand sanitizer dengan penambahan $1 \mathrm{~g}$ carbomer $\left(\mathrm{P}_{3}\right)$. Nilai viskositas yang diperoleh adalah sebesar 6500 cps. Penambahan carbomer di bawah $1 \mathrm{~g}$ menyebabkan tekstur produk terlalu encer sebaliknya, penambahan carbomer di atas $1 \mathrm{~g}$ menyebabkan tekstur produk terlalu kental. Hal ini dapat terjadi karena semakin banyak carbomer yang ditambahkan maka semakin banyak polimer carbomer yang akan saling terikat membentuk cross link. Cross linking yang terjadi membentuk matriks tiga dimensi sehingga menghasilkan gel yang sangat kental dalam waktu seketika. Sehingga semakin besar nilai viskositas maka derajat kekentalan hand sanitizer juga semakin meningkat karena jumlah polimer yang mengalami cross linking dan membentuk basis gel semakin banyak [14].

\section{Pengaruh Variasi Penambahan Carbomer} Terhadap Viskositas Hand Sanitizer

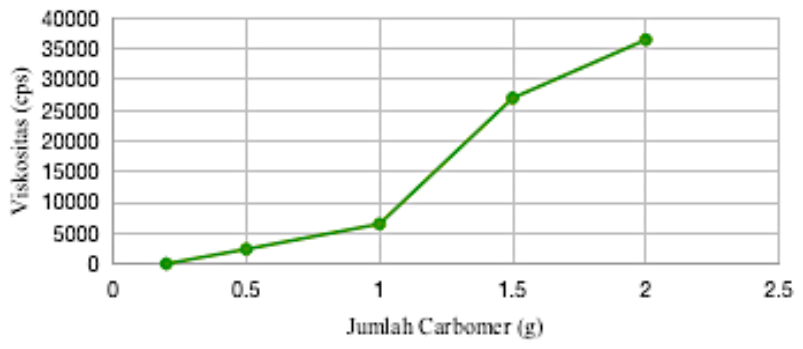

Gambar 2. Grafik Pengaruh Variasi Penambahan Carbomer Terhadap Viskositas Hand sanitizer

Berdasarkan hasil pengujian $\mathrm{pH}$ dan viskositas, maka pengujian Angka Lempeng Total (ALT), Angka Kapang Khamir (AKK), dan mikroba patogen hanya dilakukan terhadap sampel $\mathrm{P}_{3}$. Berdasarkan gambar 3 terlihat bahwa masing-masing media tidak ditumbuhi oleh bakteri, kapang, dan khamir.
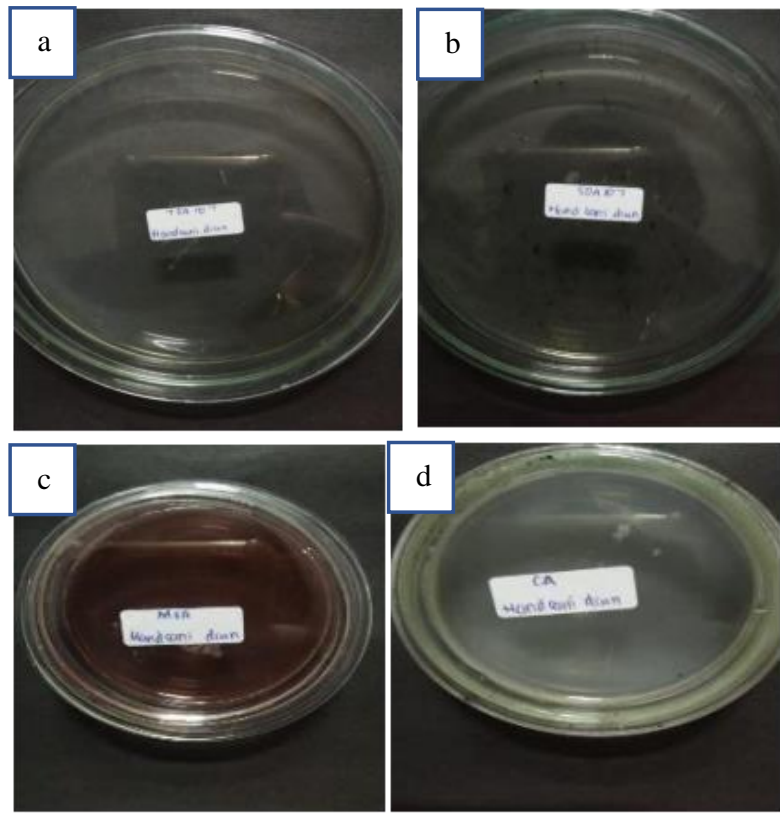

Gambar 3. Hasil Uji a) Angka Lempeng Total Pada Medium TSA, b) Angka Kapang Khamir Pada Medium SDA, c) Mikroba Patogen Pada Medium MSA, dan d) Mikroba Patogen Pada Medium CA

Dari gambar 3 dapat dilihat bahwa sampel $\mathrm{P}_{3}$ pada uji ALT, AKK, dan mikroba patogen menunjukkan hasil yang negatif, karena hand sanitizer mengandung alkohol yang memiliki kemampuan aktivitas bakteriosida yang baik terhadap bakteri. Selain itu, hand sanitizer juga mengandung antibakterial seperti triklosan yang dapat menghambat pertumbuhan bakteri pada tangan. Sedangkan carbomer berperan dalam menghambat pertumbuhan jamur dan mikroba lainnya [15]. 


\section{KESIMPULAN}

Berdasarkan hasil penelitian yang telah dijabarkan dapat disimpulkan bahwa penambahan carbomer pada formulasi hand sanitizer mempengaruhi stabilitas dan daya hambat mikroba dari hand sanitizer yang dihasilkan. Berdasarkan Standar Nasional Indonesia No. 06-2588-1992, produk hand sanitizer yang memiliki stabilitas $\mathrm{pH}$ dan viskositas yang baik serta daya bunuh mikroba yang baik adalah sampel $\mathrm{P}_{3}$.

\section{DAFTAR PUSTAKA}

[1] J. Iswara Wijaya, "Formulasi Sediaan Gel Hand sanitizer Dengan Bahan Aktif Triklosan 1,5\% dan 2\%," Jurnal Ilmiah Mahasiswa Universitas Surabaya, vol. 2, no. 1, pp. 1-14, 2013.

[2] E. P. Rini and E. R. Nugraheni, "Uji Daya Hambat Berbagai Merek Hand sanitizer Gel Terhadap Pertumbuhan Bakteri Escherichia coli dan Staphylococcus aureus," JPSCR: Journal of Pharmaceutical Science and Clinical Research, vol. 3, no. 1, p. 18, Mar. 2018, doi: 10.20961/jpscr.v3i1.15380.

[3] M. Aznury, Sofiah, and R. Prima Sari, "Produk Gel Hand sanitizer Berbahan Dasar Ekstrak Cair Daun Sirih Hijau (Piper betle Linn.) Sebagai Antiseptik," Jurnal Kinetika, vol. 11, no. 01, pp. 27-35, 2020, [Online]. Available: https://jurnal.polsri.ac.id/index.php/kimia/index.

[4] A. Asngad, A. R. Bagas, and Nopitasari, "Kualitas Gel Pembersih Tangan (Handsanitizer) dari Ekstrak Batang Pisang dengan Penambahan Alkohol, Triklosan dan Gliserin yang Berbeda Dosisnya," Bioeksperimen, vol. 4, no. 2, pp. 61-70, 2018, doi: 10.23917/bioeksperimen.v4i1.2795.

[5] W. Vicky, "Optimasi Formula Sediaan Gel Hand sanitizer Minyak Atsiri Jeruk Bergamot Dengan Gelling Agent Carbopol dan Humektan Propilen Glikol," Yogyakarta, 2016.

[6] D. Septiawan, "Perbandingan Variasi Jumlah Trietanolamin Terhadap Stabilitas Sifat Fisik Dan Sifat Kimia Gel Antiseptik Ekstrak Bunga Rosella (Hibiscus sabdariffa L.)," Surakarta, Jul. 2012.

[7] S. Dewi Syaiful, "Formulasi Dan Uji Stabilitas Fisik Gel Ekstrak Etanol Daun Kemangi (Ocimum sanctum L.) Sebagai Sediaan Hand sanitizer," Makassar, 2016.

[8] M. Shu, "Formulasi Sediaan Gel Hand sanitizer Dengan Bahan Aktif Triklosan 0,5\% dan $1 \%$," Jurnal Ilmiah Mahasiswa Universitas Surabaya, vol. 2, no. 1, pp. 1-14, 2013.

[9] A. F. Tsabitah, A. K. Zulkarnain, M. S. H. Wahyuningsih, and D. A. A. Nugrahaningsih, "Optimasi Carbomer, Propilen Glikol, dan
Trietanolamin Dalam Formulasi Sediaan Gel Ekstrak Etanol Daun Kembang Bulan (Tithonia diversifolia)," Majalah Farmaseutik, vol. 16, no. 2, pp. 111-118, Jun. 2020, doi: 10.22146/farmaseutik.v16i2.45666.

[10] T. Gunawan, "Optimasi Formula Hand sanitizer Ekstrak Buah Mengkudu (Morinda citrifolia L.) Dengan Gelling Agent CMC-Na Dan Humektan Propilen Glikol," Yogyakarta, 2017.

[11] L. Hayuning Les and W. Soeratri, "Aktivitas Antibakteri dan Stabilitas Sediaan Gel Minyak Atsiri Daun Jeruk Purut (Citrus hystrix folium)," Jurnal Farmasi Dan Ilmu Kefarmasian Indonesia, vol. 6, no. 2, pp. 74-80, 2019.

[12] M. Sukma, "Summary For Policymakers. In Intergovernmental Panel On Climate Change," in The Physical Science Basis, Cambridge University Press, 2013, pp. 1-30. doi: HTTPS://DOI.ORG/10.1017/CBO9781107415324 .004 .

[13] A. Nur Farahim, "Pemanfaatan Daun Salam Sebagai Bahan Pembuatan Hand sanitizer Dalam Bentuk Gel Dengan Penambahan Alkohol Dan Triklosan," Surakarta, 2018.

[14] B. Ande, "Pengaruh Penambahan Konsentrasi Carbopol (® 940 Pada Sediaan Sunscreen Gel Ekstrak Temu Giring (Curcuma heyneana Val.) Terhadap Sifat Fisik Dan Stabilitas Sediaan Dengan Sorbitol Sebagai Humectant," 2014.

[15] S. M. F. Situmeang and T. J. Sembiring, "Efektivitas Hand sanitizer Dalam Membunuh Kuman Di Tangan," vol. 23, no. 2, Mar. 2019. 